\title{
Pengaruh Financial Leverage Terhadap Systematic Risk Saham
}

\author{
Rahyang Rizal ${ }^{1}$; Dematria Pringgabayu ${ }^{2}$ \\ ${ }^{1,2}$ Polteknik Pajajaran ICB Bandung \\ dematria.pringgabayu@poljan.ac.id
}

\begin{abstract}
ABSTRAK
Penelitian ini meneliti pengaruh financial leverage yang diukur dengan menggunakan rasio-rasio hutang, yaitu Degree of Financial Leverage (DFL), Debt to Total Asset (DTA) dan Debt to Equity Ratio (DER) terhadap Systematic Risk (Beta) saham, serta meneliti apakah terdapat perbedaan pengaruh rasio-rasio hutang tersebutpada periode normal (tahun 2006, 2007, dan 2009) dibandingkan pada periode krisis keuangan tahun 2008. Penelitian ini menggunakan data perusahaan-perusahaan pada sektor manufaktur yang terdaftar du Bursa Efek Indonesia pada periode tahun 2006 sampai dengan 2009. Dengan menggunakan metode purposive sampling didapatkan 87 perusahaan untuk sampel penelitian. Analisis penelitian menggunakan regresi data panel dengan metode Generalized Least Square (GLS) dan tingkat kepercayaan sebesar 95\%. Dari hasil penelitian ini ditemukan bahwa DFL, DTA, dan DER berpengaruh positif terhadap systematic risk (beta) dan ditemukan bahwa tidak ada perbedaan pengaruh rasio-rasio hutang tersebut terhadap systematic risk (beta) pada periode normal dan pada periode krisis keuangan tahun 2008.
\end{abstract}

Kata kunci: degree of financial leverage (dfl)

\section{ABSTRACT}

This Research examine the influence of financial leverage measure by Debt Ratio there are Degree of Financial Leverage (DFL), Debt to Total Asset (DTA) and Debt to Equity Ratio (DER) to the systematic risk (beta) of stock, and also examine the difference influence of thus debt ratio to the systematic risk (beta) of stock in normal period and in the global financial crisis in the year of 2008. This research use the data of firms in the manufacture sector which is listed on Indonesia Stock Exchange (Bursa Efek Indonesia) for the year of 2006 untill 2009. Using the purposive sampling method founded 87 firms for the sample. Research analysis use the panel data regression with General Least Square (GLS) method and 95\% degree of confidence. The result of this research found that DFL, DTA and DER have a positive influence to the systematic risk (beta) of stock and also found that there is no difference influence of thus debt ratio to the systematic risk (beta) of stock in the normal period and on the global financial crisis in the year of 2008.

Key words: degree of financial leverage (dfl)

\section{PENDAHULUAN}

Krisis keuangan global yang terjadi di tahun 2008 berimbas ke perekonomian Indonesia sebagaimana tercermin dari gejolak di pasar modal. Indeks Harga Saham Gabungan (IHSG) pada bulan Desember 2008 ditutup pada level 1.335, turun hampir separuhnya dari awal tahun 2008, yaitu sebesar 2.627, bersamaan dengan jatuhnya nilai kapitalisasi pasar dan penurunan tajam volume perdagangan saham. Hal ini mengakibatkan risiko yang ditanggung oleh para investor yang berinvestasi pada pasar modal menjadi lebih tinggi.

Dalam berinvestasi pada pasar modal terdapat dua jenis risiko, yaitu systematic risk (risiko sistematik) dan unsystematic risk (risiko tidak sistematik). Unsystematic risk atau yang disebut juga diversiable risk adalah risiko yang dapat dihilangkan dengan melakukan diversifikasi investasi sedangkan systematic risk adalah risiko yang tidak dapat dihilangkan dengan melakukan diversifikasi investasi (Brigham dan Daves, 2007). Apabila portofolio saham hanya terdiri dari satu saham individual, maka risiko portofolio tersebut merupakan standar deviasi dari return saham tersebut. Ketika dilakukan diversifikasi, jumlah saham dalam portofolio bertambah, maka total risk dari portofolio menurun sampai dengan tingkat tertentu. 
Unsystematic risk merupakan risiko perusahaan yang spesifik, salah satunya dapat diakibatkan oleh kebijakan keuangan yang diambil oleh perusahaan, seperti misalnya dalam kebijakan untuk menggunakan hutang. Financial risk adalah risiko tambahan yang akan ditanggung oleh perusahaan jika mengambil kebijakan untuk berhutang (Brigham dan Daves, 2007). Financial risk meliputi risiko kemungkinan perusahaan mengalami gagal bayar dan juga risiko perubahan laba per lembar saham (earning per share) yang diakibatkan oleh penggunaan financial leverage (Van Horne dan Wachowicz, 2008).

Systematic risk adalah risiko yang mempengaruhi market secara keseluruhan contohnya adalah perubahan kondisi ekonomi negara, perubahan peraturan perpajakan, atau perubahan perekonomian dunia. Risiko ini tidak dapat dihilangkan dengan melakukan diversifikasi atau dengan kata lain meskipun investor membentuk suatu diversifikasi portofolio yang baik, tetap akan terpengaruh oleh systematic risk (Van Horne dan Wachowicz, 2008).

Dalam keseimbangan pasar, expected return saham diharapkan sepadan dengan systematic risk saham tersebut. Semakin tinggi systemtic risk saham, semakin tinggi expected return yang diinginkan oleh investor dari saham tersebut. Hubungan antara expected return dan systemtic risk saham dijelaskan oleh Sharpe (1964) dalam Capital Asset Pricing Model (CAPM) menggunakan beberapa asumsi, yaitu bahwa capital market efisien, investor dapat menerima informasi dengan baik, biaya transaksi rendah, tidak ada batasan dalam berinvestasi, dan tidak ada investor yang dapat mempengaruhi harga pasar. Diasumsikan juga bahwa investor memiliki persepsi yang sama terhadap kinerja saham dalam periode yang sama (Van Horne dan Wachowicz, 2008).

Penelitian yang menghubungkan antara financial leverage dengan systematic risk telah beberapa kali dilakukan. Namun demikian, penelitian serupa dengan menggunakan data capital market di Indonesia masih jarang dilakukan. Penelitian ini semakin menarik dilakukan dengan membandingkan periode krisis dan periode di luar krisis financial global.

\section{TINJAUAN PUSTAKA}

Hamada (1971) meneliti pengaruh capital structure terhadap systematic risk saham, menemukan bahwa systematic risk saham berhubungan positif dengan financial risk dari perusahaan yang menggunakan hutang dan preferred stock. Modigliani dan Miller (1963), menemukan bahwa leverage perusahaan berpengaruh positif terhadap systematic risk. Beaver dan Scholes (1970), menemukan bahwa financial leverage, asset growth, earning variability dan accounting beta berpengaruh positif terhadap systematic risk, sedangkan dividend payout, liquidity, dan asset firm size berpengaruh negatif terhadap systematic risk saham. Mandelker dan Rhee (1984), menemukan bahwa operating leverage dan financial leverage mempunyai pengaruh positif terhadap systematic risk saham. Huffman (1989), konsisten dengan Mandelker dan Rhee (1984), menemukan bahwa untuk financial leverage mempunyai pengaruh positif terhadap systematic risk saham.

Penelitian serupa dilakukan dengan menggunakan data capital market di Indonesia dilakukan oleh Sufiyati dan Naim (1998). Menggunakan metode penelitian yang dilakukan oleh Mandelker dan Rhee (1984) dan Huffman (1989), Sufiyati dan Naim (1998) menemukan bahwa operating leverage mempunyai pengaruh posiitif terhadap systematic risk saham, namun untuk financial leverage tidak mempunyai pengaruh yang signifikan terhadap systematic risk saham, hasil penelitian tersebut tidak konsisten dengan hasil penelitian yang dilakukan Mandelker dan Rhee (1984). Sufiyati dan Naim (1998) menarik kesimpulan bahwa kondisi capital market di Indonesia masih dalam keadaan thin dan segmented market sehingga kecenderungan perilaku pasar berbeda dengan capital market di negara lain yang sudah mapan seperti diantaranya New York Stock Exchange (NYSE).

\section{Systematic risk saham}

Systematic risk saham dapat diukur dengan menggunakan koefisien Beta. Beta merupakan suatu ukuran relatif dari risiko sistematik saham dalam hubungannya dengan pasar secara keseluruhan yang diukur dari fluktuasi return (Jones, 1991). Van Horne dan Wachowiz (2008) mengemukakan bahwa apabila dibandingkan antara return yang diharapkan (expected return) dari saham individual dengan market portfolio maka akan didapatkan excess return. Beta suatu saham dapat dihitung dengan teknik estimasi yang menggunakan data historis. Bukti empiris menunjukkan bahwa Beta historis mempu menyediakan informasi tentang Beta masa mendatang (Elton dan Gruber, 1994). Dalam 
penelitian ini systematic risk saham yang diproksi dengan Beta diukur dengan menggunakan single index model (Elton dan Gruber, 1995) dengan formulasi sebagai berikut:

$$
\beta=\frac{\sigma_{i m}}{\sigma_{m}^{2}}=\frac{\sum_{t}^{N}\left[\left(R_{i t}-\bar{R}_{i t}\right) \cdot\left(R_{m t}-\bar{R}_{m t}\right)\right]}{\sum_{t}^{N}\left(R_{m t}-\bar{R}_{m t}\right)^{2}}
$$

Keterangan:

$\beta_{\text {it }}$ : koefisien beta yang mengukur $\mathrm{R}_{\mathrm{i}}$ akibat perubahan $\mathrm{R}_{\mathrm{m}}$

$\mathrm{R}_{\mathrm{i}} \quad$ : return saham pada periode ke $\mathrm{t}$

$\bar{R}_{i t}$ : rata-rata return saham i pada periode ke $\mathrm{t}$

$\mathrm{R}_{\mathrm{mt}}$ : return dari indeks pasar pada periode ke $\mathrm{t}$

$\bar{R}_{m t}$ : rata-rata return dari indeks pasar pada periode ke $\mathrm{t}$

Tingkat return pasar (Rm) dihitung dengan menggunakan Indeks Harga Saham Gabungan (IHSG) (Jogiyanto, 2003). Formulasi yang digunakan dalam menghitung return pasar adalah sebagai berikut:

$$
R_{m t}=\frac{I H S G_{t}-I H S G_{t-1}}{I H S G_{t-1}}
$$

\section{Keterangan:}

$\mathrm{R}_{\mathrm{mt}} \quad$ : return dari indeks pasar pada periode ke $\mathrm{t}$

$\mathrm{IHSG}_{\mathrm{t}}$ : IHSG penutupan bulanan pada periode ke $\mathrm{t}$

IHSG $_{\mathrm{t}-1}$ : IHSG penutupan bulanan pada periode ke t-1

Tingkat return saham i (Ri) dihitung dengan menggunakan data dari perubahan harga saham yang terjadi selama periode tertentu (Jogiyanto, 2003). Formulasi yang digunakan dalam menghitung return saham adalah sebagai berikut:

Keterangan:

$$
R_{i t}=\frac{P_{i t}-P_{i t-1}}{P_{i t-1}}
$$

$\mathrm{R}_{\mathrm{it}}$ : return saham i pada periode ke $\mathrm{t}$

$\mathrm{P}_{\mathrm{it}}$ : harga penutupan bulanan saham i pada periode ke $\mathrm{t}$

$\mathrm{P}_{\mathrm{it}-1}$ : harga penutupan bulanan saham i periode ke t-1

Umumnya return saham terdiri dari perubahan harga saham dan deviden, namun dalam penelitian ini deviden tidak diperhitungkan sebagai bagian dari return saham karena pembagian deviden tidak dipengaruhi oleh kondisi pasar.

\section{Financial Leverage}

Financial Leverage timbul karena adanya biaya keuangan tetap yang harus dibayar oleh perusahaan. Kegunaan biaya keuangan tetap ini adalah untuk memperbesar pengaruh perubahan Earning Before Interest and Taxes (EBIT) pada perubahan Earning Per Share (EPS) (Gitman dan Zutter, 2010). Financial leverage berhubungan dengan risiko tambahan yang ditanggung oleh pemegang saham yang muncul diakibatkan oleh keputusan perusahaan untuk menggunakan hutang. Financial leverage menguntungkan jika pendapatan yang diterima dari penggunaan dana tersebut lebih besar dari biaya keuangan tetapnya dan merugikan apabila perusahaan tidak dapat memperoleh pendapatan sebesar biaya keuangan tetap yang harus dibayar. Semakin tinggi financial leverage akan meningkatkan volatilitas earning after tax perusahaan, hal ini akan meningkatkan beta saham perusahaan, sebaliknya financial leverage yang rendah akan mengakibatkan beta saham perusahaan rendah dikarenakan volatilitas earning after tax perusahaan juga rendah (Van Horne dan Wachowiz, 2008). Untuk mengukur kepekaan financial leverage dapat menggunakan Degree of Financial Leverage (DFL), yaitu dengan menghitung prosentase perubahan dari laba per lembar saham (earning per share) dibagi dengan prosentase earning before interest and taxes (Van Horne dan Wachowiz, 2008), dengan formulasi sebagai berikut:

$$
\mathrm{DFL}=\frac{\% \text { perubahan EPS }}{\% \text { perubahan EBIT }}
$$

Untuk melihat pengaruh hutang terhadap kinerja sebuah perusahaan, juga dapat menggunakan rasio debt to total assets. Debt to total assets (DTA) menunjukkan seberapa besar assets yang dimiliki oleh perusahaan dibiayai oleh hutang (Van Horne dan Wachowiz, 2008). Semakin besar DTA menunjukkan semakin besar biaya keuangan tetap (biaya bunga) yang harus dibayar oleh perusahaan, hal tersebut berdampak terhadap profatibilitas yang diperoleh perusahaan. Dengan biaya bunga yang semakin besar, maka EAT semakin berkurang. Sehingga, semakin tinggi DTA meningkatkan beta saham, sebaliknya DTA yang rendah akan mengakibatkan beta saham perusahaan rendah dikarenakan volatilitas EAT perusahaan juga rendah (Van Horne dan Wachowiz, 2008). DTA dapat 
dihitung dengan formulasi total debt dibagi dengan total assets, sebagai berikut:

$$
\mathrm{DTA}=\frac{\text { Total Debt }}{\text { Total Assets }}
$$

Salah satu cara untuk menilai komposisi atau struktur keuangan yang dimiliki perusahaan adalah dengan menggunakan Debt to Equity Ratio (DER). Rasio ini menunjukkan perbandingan hutang dengan modal sendiri yang dimiliki perusahaan. Semakin tinggi DER menunjukkan total hutang semakin besar dibanding dengan total modal sendiri, sehingga hal ini akan mempengaruhi hak dari pemegang saham untuk mendapatkan return dikarenakan penghasilan perusahaan berkurang karena semakin besarnya kewajiban perusahaan untuk membayar bunga. Semakin tinggi DER akan meningkatkan volatilitas EAT, hal ini akan meningkatkan beta saham perusahaan, sebaliknya DER yang rendah akan mengakibatkan beta saham perusahaan rendah dikarenakan volatilitas EAT perusahaan juga rendah (Van Horne dan Wachowiz, 2008). DER dapat dihitung dengan formulasi total debt dibagi dengan total share holder's equity (Van Horne dan Wachowiz, 2008), sebagai berikut:

$$
\mathrm{DER}=\frac{\text { Total Debt }}{\text { Total Equity }}
$$

\section{Hubungan Financial Leverage dan Beta Saham}

Perusahaan umumnya mempunyai sumber pendanaan yang berasal dari saham dan dari hutang. Hal ini berarti beta saham sebuah perusahaan dipengarui oleh beta perusahaan itu sendiri dan beta dari financial leverage (Sharpe, Alexander dan Bailey, 1999). Misalnya dua buah perusahaan mempunyai kesamaan dari segala segi, kecuali dari segi pendanaan. Perusahaan pertama mempunyai hutang dan perusahaan kedua tidak mempunyai hutang. Hal ini menyebabkan meskipun kedua perusahaan tersebut mempunyai EBIT yang sama, namun kedua perusahaan tersebut akan mempunyai EAT yang berbeda, dikarenakan perusahaan pertama harus membayar biaya bunga atas hutang, sedangkan perusahaan kedua tidak. Dalam kondisi ini beta saham perusahaan pertama lebih besar daripada beta perusahaan kedua. Hal ini dikarenakan penggunaan hutang menyebabkan variabilitas laba yang akan dibagikan kepada pemengang saham lebih besar.

Modigliani dan Miller (1963) dalam Modigliani dan Miller (1963), mengemukakan sebuah proposisi bahwa penggunaan hutang dapat meningkatkan value dari perusahaan dikarenakan bunga yang dibayar bersifat tax deductible. Selain itu, penggunaan hutang memberikan sinyal kepada investor, ketika perusahaan kurang yakin prospek bisnisnya menguntungkan perusahaan akan mengeluarkan saham untuk membiayai bisnis tersebut, sebaliknya ketika perusahaan yakin prospek bisnisnya menguntungkan perusahaan akan membiayai bisnis tersebut dengan berhutang. Hamada (1971) dalam Brigham dan Daves (2007), menerangkan hubungan financial leverage dan beta saham perusahaan berdasar model CAPM dan proposisi Modigliani dan Miller dalam sebuah persamaan yang dikenal dengan nama Hamada Equation, sebagai berikut:

$$
\beta=\beta_{U}+\beta_{U} \cdot(1-\tau) . \mathrm{D} / \mathrm{E}
$$

Keterangan:

$\beta$ : Beta saham perusahaan

$\beta_{\mathrm{U}}$ : Unlevered Common Stock Beta

$\tau$ : Corporate Income Tax (Pajak Penghasilan Perusahaan)

D : Debt (Hutang)

E : Equity

Pada persamaan diatas dapat dilihat bahwa $\beta_{\mathrm{U}}$ mengukur operating risk, sedangkan $\beta_{\mathrm{U}}$.(1- $\left.\tau\right)$.D/E digunakan untuk mengukur financial leverage. Mandelker dan Ree (1984) memodifikasi Hamada equation dengan menambahkan $\beta_{\mathrm{D}}$ (beta debt) untuk menambahkan risiko dari penggunaan hutang seperti ditunjukkan pada persamaan sebagai berikut:

$$
\beta=\beta_{U}+\left(\beta_{U}-\beta_{D}\right) . \mathrm{D} / \mathrm{E} .(1-\tau)
$$

Pengaruh debt dan financial leverage terhadap beta saham perusahaan dapat ditentukan melalui langkah-langkah sebagai berikut (Sharpe, Alexander dan Bailey, 1999):

1. Menentukan market value dari perusahaan yang menggunakan hutang (levered firm), dengan formulasi sebagai berikut:

$\mathrm{V}_{\mathrm{L}}=\mathrm{D}+\mathrm{E}$

2. Menentukan market value dari perusahaan yang tidak menggunakan hutang (unlevered firm) dengan formulasi sebagai berikut:

$\mathrm{V}_{\mathrm{U}}=\mathrm{V}_{\mathrm{L}}-\mathbf{\tau} \mathrm{D}$

3. Menentukan beta perusahaan $\left(\beta_{\text {firm }}\right)$ setelah mengestimasi beta hutang perusahaan $\left(\beta_{D}\right)$ dan 
beta saham perusahaan $\left(\beta_{\text {equity }}\right)$ dengan formulasi sebagai berikut:

$$
\beta_{\text {firm }}=\beta_{\text {Debt }} \frac{(1-\tau) D}{V_{U}}+\frac{E}{V_{U}}
$$

4. Menentukan pengaruh degree of leverage terhadap beta saham dengan formulasi sebagai berikut:

$$
\beta_{\text {equity }}=\beta_{\text {firm }}+\left(\beta_{\text {firm }}-\beta_{\text {Debt }}\right) \text {.D } / \text { E. }(1-\boldsymbol{\tau})
$$

Dari persamaan tersebut di atas dapat dilihat bahwa jika diasumsikan bahwa nilai $\beta_{\text {firm }}$ dan $\beta_{\mathrm{D}}$ tidak berubah, maka kenaikan DER akan meningkatkan $\beta_{\text {equity, dikarenakan DER yang }}$ tinggi akan meningkatkan volatilitas EAT perusahaan, sebaliknya DER yang rendah akan mengakibatkan $\beta_{\text {equity }}$ rendah dikarenakan volatilitas EAT juga rendah.

Pengaruh krisis keuangan global tahun 2008 terhadap Financial Risk perusahaan dan Systematic Risk saham di Pasar Modal Indonesia

Krisis keuangan global yang terjadi di tahun 2008 yang ditandai dengan bangkrutnya Lehman Brother, sebuah bank investasi terbesar di Amerika Serikat yang diikuti oleh kesulitan keuangan yang semakin parah di sejumlah lembaga keuangan berskala besar di Amerika Serikat, Eropa dan Jepang berimbas ke perekonomian Indonesia sebagaimana tercermin dari jatuhnya nilai tukar rupiah terhadap dollar Amerika Serikat dan gejolak di Pasar Modal Indonesia.

Pelemahan nilai tukar rupiah tersebut dan adanya kebijakan Bank Indonesia untuk menaikkan suku bunga menjadi $9,5 \%$ mengakibatkan perusahaan yang mempunyai kewajiban membayar pokok hutang dan bunga mengalami peningkatan dalam biaya keuangan tetapnya. Hal ini berpengaruh terhadap meningkatnya financial risk yang ditanggung perusahaan dan mengakibatkan menurunnya EAT.

Di pasar saham, volume perdagangan saham dan Indeks Harga Saham Gabungan (IHSG) mengalami tekanan kuat, hal ini memaksa otoritas bursa menghentikan perdagangan pada Oktober 2008. IHSG menurun drastis, dari sebesar 2.627 pada awal tahun menjadi 1.355 pada akhir tahun 2008 . Penyebab Pasar Modal Indonesia terkena imbas krisis keuangan global, salah satunya dikarenakan cukup tingginya proporsi investor asing, yaitu menurut data Kustodian Sentra Efek Indonesia
(KSEI) per tanggal 31 Juli 2008 sebesar 64\%. Investor asing yang terkena imbas krisis keuangan global mengalami kesulitan likuiditas sehingga terpaksa menarik dananya dari Pasar Modal Indonesia. Aksi jual dengan nilai dan volume yang cukup besar menyebabkan IHSG turun. Hal ini mengakibatkan return saham menjadi turun, sehingga menyebabkan risiko yang ditanggung investor meningkat.

Dari kondisi tersebut di atas, dibuat kerangka pemikiran dalam penelitian ini, yaitu financial risk meliputi risiko kemungkinan perusahaan mengalami gagal bayar dan juga risiko perubahan laba per lembar saham (earning per share) yang diakibatkan oleh penggunaan financial leverage, yang diukur dengan DFL, DTA, dan DER akan meningkatkan volatilitas EAT perusahaan yang akan meningkatkan beta saham perusahaan (Van Horne dan Wachowicz,2008). Dampak tersebut akan mengalami peningkatan pada periode krisis keuangan global tahun 2008.

\section{METODE PENELITIAN}

Metode penelitian yang digunakan adalah Verificatife Research Method, yaitu menggunakan data historis untuk menjelaskan hubungan pengaruh antar variabel dengan melakukan pengujian hipotesis. Pengujian hipotesis dalam penelitian ini menggunakan analisis regresi dengan panel data, yaitu menggabungkan antara data time series dan data cross section. Panel data atau disebut juga data longitudinal adalah sekelompok data individual yang diteliti selama rentang waktu tertentu. Ada beberapa manfaat menggunakan panel data dibandingkan time series atau cross section saja, diantaranya mengurangi kolinearitas, meningkatkan derajat kebebasan, dan memberikan informasi lebih banyak daripada cross section atau time series saja (Gujarati, 2004).

\section{Operasionalisasi Variabel}

Variabel dependen yang digunakan dalam penelitian ini adalah systematic risk saham yang diproksikan dengan menggunakan beta, sedangkan variabel independen yang digunakan adalah DFL, DTA, dan DER, serta variabel Dummy (D) yang digunakan untuk mengetahui perbedaan pengaruh variabel independen pada periode normal dan pada periode krisis keuangan global tahun 2008. Daftar operasionalisasi variabel dalam penelitian ini adalah sebagai berikut: 


\begin{tabular}{clcc}
\hline No & $\begin{array}{l}\text { Variabel/(Jenis } \\
\text { Variabel) }\end{array}$ & Formulasi Pengukuran \\
\hline 1 & Beta/(Dependen) & $\beta=\frac{\sigma_{\text {im }}}{\sigma_{m}^{2}}$ \\
\hline 2 & $\begin{array}{l}\text { DFL } \\
\text { (Independen) }\end{array}$ & / & DFL $=\frac{\% \text { perubahan EPS }}{\% \text { perubahan EBIT }}$ \\
\hline 3 & $\begin{array}{l}\text { DTA } \\
\text { (Independen) }\end{array}$ & $/$ & DTA $=\frac{\text { Total Debt }}{\text { Total Assets }}$ \\
\hline 4 & $\begin{array}{l}\text { DER } \\
\text { (Independen) }\end{array}$ & $/$ & DER $=\frac{\text { Total Debt }}{\text { Total Equity }}$ \\
\hline 5 & $\begin{array}{l}\text { Dummy } \\
\text { (Independen) }\end{array}$ & $/$ & $\begin{array}{l}\mathrm{D}=0, \text { periode normal } \\
\mathrm{D}=1, \text { periode krisis }\end{array}$ \\
\hline
\end{tabular}

\section{Data dan Sampel}

Data yang digunakan dalam penelitian ini adalah data sekunder yang sumbernya diperoleh dari Indonesian Capital Market Directory (ICMD) untuk data laporan keuangan sebagai dasar perhitungan DFL, DTA, dan DER, sedangkan data harga saham dan IHSG untuk menghitung beta saham diperoleh dari www.finance.yahoo.com.

Sampel yang digunakan adalah perusahaan manufaktur yang tercatat di Bursa Efek Indonesia (BEI) periode tahun 2006, 2007, 2008 dan 2009. Pengambilan sampel menggunakan metode purposive sampling, dengan kriteria sebagai berikut:

1. Saham perusahaan tercatat dan aktif diperdagangkan setiap bulan di BEI berturutturut untuk periode tahun 2006 - 2009; dan

2. Perusahaan tersebut menerbitkan laporan keuangan tahunan yang lengkap dan dipublikasi di ICMD untuk periode tahun 2006-2009.

Untuk data penelitian tahun 2006, 2007 dan 2009, merupakan data penelitian untuk periode normal diberi variabel dummy (D) yang bernilai 0 , sedangkan data tahun 2008 merupakan data penelitian untuk periode krisis diberi variabel dummy (D) yang bernilai 1.

\section{Rancangan Analisis dan Pengujian Hipotesis}

Analisis yang digunakan dalam penelitian ini adalah regresi data panel dengan menggunakan Generalized Least Square (GLS). Metode GLS dapat mengatasi masalah heteroskedastisitas (varian yang tidak konstan) dan masalah autokorelasi (korelasi antara satu variabel gangguan dengan variabel gangguan yang lain) (Widarjono, 2009). Variabel-variabel yang digunakan dalam penelitian ini berhubungan dengan hutang yang digunakan oleh perusahaan, sehubungan dengan hal tersebut untuk menghindari adanya multikolinearitas dalam model regresi, maka pengujian hipotesis dilakukan dengan menggunakan uji parsial untuk masing-masing variabel independen. Model persamaan yang digunakan adalah sebagai berikut:
1. Persamaan 1, untuk menguji pengaruh DFL terhadap Beta

Beta $_{i t}=\alpha_{0}+\beta_{1} D F L_{i t}+\gamma_{1}\left(\right.$ D. $\left.D F L_{i t}\right)+e_{i t}$

2. Persamaan 2 , untuk menguji pengaruh DTA terhadap Beta

Beta $_{i t}=\alpha_{0}+\beta_{2} D F L_{i t}+\gamma_{2}\left(\right.$ D. $\left.D F L_{i t}\right)+e_{i t}$

3. Persamaan 3 , untuk menguji pengaruh DER terhadap Beta

Beta $_{i t}=\alpha_{0}+\beta_{3} D F L_{i t}+\gamma_{3}\left(\right.$ D. $\left.D F L_{i t}\right)+e_{i t}$

Keterangan:

$\alpha_{0} \quad$ : Konstanta (intersep) persamaan regresi

$\beta_{1}, \beta_{2}, \beta_{3}$ : Kemiringan (slope)/koefisien regresi variabel DFL, DTA, dan DER

$\gamma_{1}, \gamma_{2}, \gamma_{3}$ : Koefisien regresi variabel dummy (D) yang menunjukkan perbedaan pengaruh variabel independen pada periode normal dan pada periode krisis.

Hipotesis yang akan diuji dalam penelitian ini adalah sebagai berikut:

1. Hipotesis pertama $\left(\mathrm{H}_{1}\right)$ : $\mathrm{H}_{0}$ ditolak jika $\beta_{1} \leq 0$ dan $H_{a}$ diterima jika $\beta_{1}>0$, yang berarti bahwa DFL berpengaruh positif terhadap beta saham.

2. Hipotesis pertama $\left(\mathrm{H}_{2}\right): \mathrm{H}_{0}$ ditolak jika $\beta_{2} \leq 0$ dan $H_{a}$ diterima jika $\beta_{2}>0$, yang berarti bahwa DTA berpengaruh positif terhadap beta saham.

3. Hipotesis pertama $\left(\mathrm{H}_{3}\right): \mathrm{H}_{0}$ ditolak jika $\beta_{3} \leq 0$ dan $\mathrm{H}_{\mathrm{a}}$ diterima jika $\beta_{3}>0$, yang berarti bahwa DER berpengaruh positif terhadap beta saham.

4. Hipotesis pertama $\left(\mathrm{H}_{4}\right): \mathrm{H}_{0}$ ditolak jika $\gamma_{1} \leq 0$ dan $\mathrm{H}_{\mathrm{a}}$ diterima jika $\gamma_{1}>0$, yang berarti bahwa pengaruh DFL terhadap beta saham pada periode krisis keuangan global tahun 2008 lebih besar dibandingkan pada periode normal.

5. Hipotesis pertama $\left(\mathrm{H}_{5}\right): \mathrm{H}_{0}$ ditolak jika $\gamma_{2} \leq 0$ dan $\mathrm{H}_{\mathrm{a}}$ diterima jika $\gamma_{2}>0$, yang berarti bahwa pengaruh DTA terhadap beta saham pada periode krisis keuangan global tahun 2008 lebih besar dibandingkan pada periode normal.

6. Hipotesis pertama $\left(\mathrm{H}_{6}\right): \mathrm{H}_{0}$ ditolak jika $\gamma_{3} \leq 0$ dan $\mathrm{H}_{\mathrm{a}}$ diterima jika $\gamma_{3}>0$, yang berarti bahwa pengaruh DER terhadap beta saham pada periode krisis keuangan global tahun 2008 lebih besar dibandingkan pada periode normal.

\section{HASIL DAN PEMBAHASAN}

Uji Hausman atas data penelitian dari masingmasing model persamaaan menunjukkan hasil sebagai berikut: 


\begin{tabular}{lcc}
\hline No & Model Persamaan & $\begin{array}{c}\text { Hasil } \\
\text { Uji }\end{array}$ \\
\hline 1 & Beta $_{i t}=\alpha_{0}+\beta_{1} D F L_{i t}+\gamma_{1}\left(\mathrm{D} . D F L_{i t}\right)+e_{i t}$ & 42,28 \\
\hline 2 & Beta $_{i t}=\alpha_{0}+\beta_{2} D F L_{i t}+\gamma_{2}\left(\mathrm{D} . D F L_{i t}\right)+e_{i t}$ & 19,64 \\
\hline 3 & Beta $_{i t}=\alpha_{0}+\beta_{3} D F L_{i t}+\gamma_{3}\left(\mathrm{D} . D F L_{i t}\right)+e_{i t}$ & 36,22 \\
\hline
\end{tabular}

Dari hasil uji Hausman di atas, menunjukkan nilai statistik uji Hausman untuk model persamaan 1 sebesar 42,28, persamaan 2 sebesar 19,64, dan persamaan 3 sebesar 36,22, sedangkan nilai Chi Square dengan degree of freedom sebanyak 2 (jumlah variabel independen termasuk dummy) pada significant level $1 \%=9,21 \%, \quad 5 \%=5,99$, dan $10 \%=4,61$. Hal ini berarti nilai uji statistik Hausman yang dihasilkan lebih besar daripada nilai kritis $C h i$ Square. Dengan demikikan berdasarkan uji Hausman, model yang tepat untuk menganalisis persamaan regresi yang dugunakan dalam penelitian ini adalah dengan menggunakan pendekatan modle fixed effect.

Hasil pengujian hipotesis dengan menggunakan uji t parsial satu sisi positif dengan menggunakan $\alpha$ $=5 \%$, adalah sebagai berikut:

1. Hasil pengujian hipotesis pertama, menguji bahwa variabel DFL berpengaruh positif terhadap beta, didapatkan hasil $\mathrm{t}$ hitung sebesar 7,604 sedangkan nilai t kritis sebesar 1,645, berarti nilai $\mathrm{t}$ hitung > nilai t kritis, maka $\mathrm{H}_{0}$ ditolak dan $\mathrm{H}_{\mathrm{a}}$ diterima, yang berarti bahwa DFL berpengaruh positif terhadap beta.

2. Hasil pengujian hipotesis kedua, menguji bahwa variabel DTA berpengaruh positif terhadap beta, didapatkan hasil $\mathrm{t}$ hitung sebesar 23,020 sedangkan nilai $\mathrm{t}$ kritis sebesar 1,645 , berarti nilai t hitung > nilai t kritis, maka $\mathrm{H}_{0}$ ditolak dan $\mathrm{H}_{\mathrm{a}}$ diterima, yang berarti bahwa DTA berpengaruh positif terhadap beta.

3. Hasil pengujian hipotesis ketiga, menguji bahwa variabel DER berpengaruh positif terhadap beta, didapatkan hasil $\mathrm{t}$ hitung sebesar 16,247 sedangkan nilai $\mathrm{t}$ kritis sebesar 1,645 , berarti nilai $\mathrm{t}$ hitung > nilai t kritis, maka $\mathrm{H}_{0}$ ditolak dan $\mathrm{H}_{\mathrm{a}}$ diterima, yang berarti bahwa DER berpengaruh positif terhadap beta.

4. Hasil pengujian hipotesis keempat, menguji bahwa variabel DFL terhadap beta saham pada periode krisis keuangan global tahun 2008 lebih besar dibandingkan pada periode normal, didapatkan hasil $\mathrm{t}$ hitung sebesar 1,431 sedangkan nilai $t$ kritis sebesar 1,645 , berarti nilai t hitung < nilai t kritis, maka $\mathrm{H}_{0}$ diterima dan $\mathrm{H}_{\mathrm{a}}$ ditolak, yang berarti bahwa pengaruh
DFL terhadap beta pada periode krisis keuangan global tahun 2008 tidak lebih besar dibandingkan pada periode normal.

5. Hasil pengujian hipotesis kelima, menguji bahwa variabel DTA terhadap beta saham pada periode krisis keuangan global tahun 2008 lebih besar dibandingkan pada periode normal, didapatkan hasil $\mathrm{t}$ hitung sebesar 1,289 sedangkan nilai $\mathrm{t}$ kritis sebesar 1,645, berarti nilai t hitung < nilai $\mathrm{t}$ kritis, maka $\mathrm{H}_{0}$ diterima dan $\mathrm{H}_{\mathrm{a}}$ ditolak, yang berarti bahwa pengaruh DTA terhadap beta pada periode krisis keuangan global tahun 2008 tidak lebih besar dibandingkan pada periode normal.

6. Hasil pengujian hipotesis keempat, menguji bahwa variabel DER terhadap beta saham pada periode krisis keuangan global tahun 2008 lebih besar dibandingkan pada periode normal, didapatkan hasil $\mathrm{t}$ hitung sebesar 0,063 sedangkan nilai $\mathrm{t}$ kritis sebesar 1,645 , berarti nilai t hitung < nilai t kritis, maka $\mathrm{H}_{0}$ diterima dan $\mathrm{H}_{\mathrm{a}}$ ditolak, yang berarti bahwa pengaruh DER terhadap beta pada periode krisis keuangan global tahun 2008 tidak lebih besar dibandingkan pada periode normal.

\section{KESIMPULAN DAN SARAN}

Dari hasil penelitian diperoleh kesimpulan bahwa, financial risk, yaitu risiko perusahaan mengalami gagal bayar dan juga risiko perubahan laba per lembar saham yang diakibatkan oleh penggunaan financial leverage, yang diukur dengan DFL, DTA, dan DER berpengaruh positif terhadap peningkatan beta saham perusahaan.

Pengaruh DFL, DTA dan DER periode krisis keuangan global tahun 2008 tidak lebih besar dibandingkan pada periode normal. Pengaruh krisis keuangan global tahun 2008 baru berimbas ke Pasar Modal di Indonesia pada akhir triwulan ketiga tahun 2008, yang ditandai dengan terus menurunnya IHSG, sehingga BEI terpaksa melakukan suspend perdagangan tanggal 9 dan 10 Oktober 2008. Turunnya IHSG disebabkan penarikan dana oleh Investor asing yang mengalami kesulitan likuiditas. Namun, pada bulan Februari 2009, Investor asing kembali menempatkan dana di Pasar Modal Indonesia dan bursa kembali membaik. Sehingga dampak krisis keuangan global tahun 2008 sangat minim pengaruhnya terhadap perdagangan di BEI.

Berdasarkan hasil penelitian ini, saran bagi investor yang akan melakukan analisa fundamental untuk berinvestasi, dapat menggunakan rasio-rasio financial leverage, diantaranya DFL, DTA dan DER 
untuk menganalisa tingkat systematic risk saham perusahaan. Bagi emiten, sebbaiknya mempertimbangkan bahwa kebijakan penggunaan hutang dapat meningkatkan systematic risk saham, hal ini kurang disukai oleh Investor yang mempunyai kecenderungan risk aversion. Untuk selanjutnya, apabila akan dilakukan penelitian serupa, adapat menggunakan sampel pada sektor lainnya dan series data yang lebih panjang, agar pengukuran dampak krisis keuangan global pada tahun 2008 dapat lebih mendalam.

\section{DAFTAR PUSTAKA}

Altman, Edward I. \& Hotchkiss, Edith.2006. Corporate Financial Distress and Bankcruptcy. New Jersey: John Wiley \& Sons Inc.

Beaver, William. \& Scholes, Myron. 1970. The Association Between Market Determined and Accounting Determined Risk Measures. Accounting Reviews: 654-682Brigham, Eugene F. \& Daves, Philip R.2007. Intermediate Financial Managementh $9^{\text {th }}$ Edition. New York: Thomson Corporation.

Elton, Edwin J. \& Gruber, Martin J.2003. Modern Portofolio and Investment Analysis. New Jersey: John Wiley \& Son, Inc.

Ghozali, Imam. 2009. Analisis Multivariate Lanjutan Dengan Program SPSS. Semarang: Badan Penerbit Univeristas Diponegoro.

Ghozali, Imam. 2011. Aplikasi Analisis Multivariate Dengan Program IBM SPSS 19. Semarang: Badan Penerbit Univeristas Diponegoro.

Gitman, Lawrence J. \& Zutter, Chad J.2010. Managerial Finance 13th Edition. Boston: The Prentice Hall.

Gujarati, Damodar N. 2004. Basic Econometrics $4 t^{h}$ Edition. New York: Mc Graw Hill.

Hamada, Robert S. 1971. The Effect of The Firm's Capital Structue on The Systematic Risk of Common Stocks. The Journal of Finance vol 27: 435-452.

Huffman, Stephen P. 1989. The Impact of Degree of Operating Leverage and Degree of Financial Leverage on The Systematic Risk of Common Stock: Another Look. Journal of Finance and Accounting 28:83.

Jogiyanto, H.M. 2003. Teori Portfolio dan Analisis Investasi. Yogyakarta: BPFE.

Jones, Charles. 1991. Investmen Analysis and Management $3^{\text {rd }}$ Edition. New York: John Wiley and Son, Inc.
Mandelker, Gerson N. \& Rhee, S. Ghon. 1984. The Impact of the Degree of Operating and Financial Leverage on Systematic Risk of Common Stocks. The Journal of Financial and Quantitative Analysis vol 19: 45-47.

Sharpe, W., Alexander, G., dan Bailey, J. 1999. Investment. New Jersey: The Prentice Hall.

Sufiati. \& Na'im, Ainun. 1998. Pengaruh Leverage Operasi dan Leverage Finansial Terhadap Risiko Sistematik Saham: Studi Pada Perusahaan Publik di Indonesia. Jurnal Ekonomi dan Bisnis Indonesia vol 13: 57-69.

Van Horne, James C. Wachowicz, John M. 2011. Fundamentals of Financial Management. Harlow: The Prentice Hall.

Widarjono, Agus. 2009. Ekonometrika Pengantar dan Aplikasinya. Yogyakarta: Ekonisia.

$<$ http://finance.yahoo.com/q/cp?s=^JKSE+Compone nts $>$

<http://ksei.co.id/content.asp?id=10\&bhs=I> 